\title{
LAW AND ETHICS OF STRIKES IN THE NIGERIAN HEALTH SYSTEM
}

KALADA GODSON MCFUBARA

\begin{abstract}
Despite that health services are essential, health sector strikes have continued. The purpose here was to examine the legal and ethical justification of strikes in the Nigerian health sector. Documentary analysis and literature reviews were carried out. It was found that the Trade Disputes Act and the National Health Act do not provide for strikes by health workers. Virtue ethics does not also recognize health sector strikes. Although definite claim to the rightness or wrongness of the actions of health workers may be difficult, compliance or non-compliance to professional pledges can be associated with rightness or wrongness of their actions. It is concluded that trustees of the public health have a duty and are under obligation to respect human dignity at all times. This is because health sector strikes reflect a loss of the values of professional ethics by health workers. Discussions in bioethics among health workers can redress this loss by targeting the affective domain in health workers' learning during training.
\end{abstract}

KEYWORDS: Compliance, Deliberate acts, Duty, Health workers, Obligation.

\section{INTRODUCTION}

According to Stone (1995:7) there is a huge interplay between what is ethical and what is legal, the latter being determined by the former. Law enforces minimum standard of conduct, while ethics promotes optimum standard of behaviour. The Trade Union (amendment) Act (Federal Republic of Nigeria, 2005) identifies health services as essential services. The concept of essential services refers to services that are indispensable to or absolutely necessary for normal human functioning. In the United States of America although government employees and workers in the essential services of airline, rail and fire, are prohibited from strikes, Kemp (op. cit) observed that the health sector strike is the one most controversial. In fact, it is because of its essential nature that even in times of restricted movement like curfew, health workers are not affected or they are exempted from such restrictions.

Nigeria began to experience strikes in the health sector in the early 1970s. Between
1975 and 1984 there were four such major strikes by the medical profession (Alubo,1986). These were virtually at three yearly (cyclical) intervals. A strike action refers to work stoppage by employees to pressure employers to change policies. The Sun Newspaper of 20 June 2014 reported that since 2000 there had been annual strike - for all kinds of reason. Earlier, on June 23, 2011 the Medical and Dental Council of Nigeria (MDCN) held a stakeholders meeting, and this was in the backdrop of what the Council described as "recent series of strike action." In a communique issued at the end of that meeting it was emphasised that "while the Code of Ethics of our profession allows medical and dental practitioners to down tools under extreme circumstances that will be quite rare, when such industrial action occurs the care of our patients is protected".

Moreover the Code of MDCN stipulates that "no patient can be abandoned in the midst of his or her treatment ...." The two phrases, extreme circumstances that will be quite rare, and, no patient can be abandoned, when

Kalada Godson Mcfubara, Department of Community Medicine, Niger Delta University, Bayelsa State,

Nigeria. 
examined in the light of the Trade Disputes (essential services) Act (Federal Republic of Nigeria, 2004) and the National Health Act (Federal Republic of Nigeria, 2014) of the Laws of Nigeria suggest that neither the Acts nor the MDCN Code of ethics intends to give right for cessation of work by workers in the health sector of the economy. Thus under the Common Law, a strike, especially in the essential services is a breach of the contract of employment. The Trade Union (amendment) Act (Federal Republic of Nigeria, 2005) acknowleges this when it states that "no person or trade union or employee shall take part in a strike or lockout or engage in any conduct on contemplation for furtherance of a strike or lockout unless the person or trade union or employee is not engaged in the provision of essential service".

Despite the above provisions in the law and the code of professional conduct, of all the essential services the health sector seems to be the most affected by strikes. In Nigeria it has almost become a common experience that if the Association of Resident Doctors (ARD) is not on strike, the Nigerian Medical Association (NMA) will be. Where the ARD and NMA are not it would be the Joint Health Services Union (JOHESU). JOHESU comprises of all the other frontline health workers except doctors. This paper discusses health sector strikes in the light of the code of ethics of the health professions and the laws of the Federal Republic of Nigeria.

\section{Ethical approaches in health care analysis}

There are three approaches to discussions on ethics. These are deontology, utilitarianism and virtue. According to Kemp (2013) virtue ethics is the one most acceptable to the medical profession. This can also be true of the other professions in the health sector. For instance, as purity is a virtue in nursing practice, so is the virtue of devotion common in the pledges made by the medical, nursing, pharmacy and medical laboratory science inductees. Meanwhile although medical ethics has been described as the basis of sound and safe professional practice (Ezeani, 2000), a study by Ogundiran and Adebamowo (2012) showed that medical students are not given the virtuous ethics education they need to prepare them for the task ahead. This therefore suggests that the approach to or content of ethics education in Nigeria is still below the desired level.
The health sector in Nigeria has had varied experiences from its operators such that even the virtues of devotion and purity have been brought to doubt. Apart from SIN, which McFubara, (2014a) identified as self interest, impunity and nepotism, strike by health workers, is one of the experiences that have brought these virtues to doubt. In fact, incessant strikes have become impurity in the Nigerian health system. This impurity can be identified in the comment by Dr. Stephen Oluwole, President of the Medical and Dental Consultants Association of Nigeria (MDCAN), who stated that "the cycles of strikes and counter strikes .... have weakened the health services" (Ikuomola, 2015). In science it is an impurity that can weaken the strength of a material. Here the same can be said of a value system such as the health system, whereby incessant withdrawal of services is weakening the effectiveness of the service.

\section{A right for health workers to strike?}

If there is an absence of emphasis on the virtues of professional service during training, it does not mean that withholding professional service during practice by essential services providers is encouraged. The right which trade unions have in the Trade Disputes Act is to determine their membership and have an office (Obebe and Adu, 2011), as well as right not to be injured, suffer damage or disease transmission (S.21 National Health Act). These do not translate to the positive right to strike. But despite the rules and laws strike actions have never ceased in the health sector. Citing Orifowomo, Agboke (2014) indicated that the right to strike must be about terms of employment and physical condition of work. For instance, in 2010 when the NMA in Edo State went on strike because their members were being kidnapped, it was not about terms of employment. Kidnapping has been affecting virtually every sector of the Nigerian economy. Thus it is not the right of any health worker to embark on strike. Rather the right to strike can be derived from the principle of collective bargaining, which according to Ahmed (2014) is an essential principle. Workers may therefore exercise their freedom (not right) to strike. Even so, when Amadi (1996:80) suggests that workers have a right to strike what he meant is that the right is an integral and intrinsic part of the contract of employment. However, McFubara (2014b) has argued that within the health sector if certain actions, including the freedom ('right') to strike, 
are not carefully treated and controlled they can infringe on the right of the patient to health and invariably the right to life.

The other aspect of the matter is, if as Agboke (op. cit.) adduces by citing Amadi, that there is a right to strike which cannot be contested under law, freedom to strike can certainly be contested. But where the statutory body that regulates a profession has not declared an action unlawful, it may be difficult for that action to be contested against. That is why where Governments have failed to restrain incessant strikes which in the eyes of the law is unlawful, it is because the regulatory bodies concerned have been silent and thus the Government too, having considered the political cost, has tended to tolerate those strikes.

\section{Duty and obligation for health care}

In their commitments at induction, the various health workers pledge to devote themselves to the best interest of their patients. This is on the acceptance that they are called to save life. In Islam the sanctity of life and seeking cure are two key principles of medical ethics (Hamed, 2013) and they impose an obligation on the practitioner to save life. The Medical and Dental Council of Nigeria (MDCN) also has as one of its principal objectives of practice the respect for human dignity. In effect what these principles and objectives mean is that even the freedom to strike is not sacrosanct as it touches on the life of the patient or would be patient. But that does not suggest that the genuine demands of health workers should be discountenanced. Rather it calls for caution. Apostles Paul and Peter in their separate letters to the churches (The Holy Bible, KJV 1Corrinthians 8:13 and 1Peter 2:16) caution that freedom should not be exercised in such a way that it hurts the interest of the other person.

Thus to ensure that actions and inactions of health workers conform to their duties and obligations laws are enacted to enjoin or prohibit skewed interference in the patient-practitioner relationship. Laws impose a duty where duty presupposes a claimable indebtedness to someone. On the other hand an obligation suggests a commitment that is binding and this can be found in the pledges obligors (professionals) make to their obligees (audience or potential patients) at the time of being inducted into their various professions. For instance, in the
Physicians Oath the statement that 'the health of my patient shall be my first consideration' implies that under no avoidable circumstance shall the patient be abandoned. But strikes are avoidable even if it means going into negotiation for as long as it takes.

In Britiain strikes are intercalated to allow for continuity in the duty of care. In fact, during strikes (as by other professions) the British Medical Association (BMA) advises its members to prepare for any eventual need for them to take on jobs they may not normally have to undertake. This advise emphasises adherence to duty and obligation owed by the medical profession to the patient (BMA, 2015). Thus in times of strike in Nigeria one can say that there is always a breach of the duty of care because it is foreseeable that when patients are discharged in the middle of their treatment, or left unattended to, due to a strike action, there can be an avoidable harm to be inflicted. For example, as reported in Nigeria health watch, 'how strikes are killing the public health...', the death of a professor at UCH Ibadan and a lady in Enugu, could have been avoided but for the cycles of strikes in 2014. Thus strikes negate both the duty in law and the obligation in oath by health workers.

\section{The value in a pledge or an oath}

If there is no value in the pledge made or oath taken by professionals, then there will be no need for the pledge or oath in the first place. Yet most of the health care professions require new entrants (inductees) to make commitments from the profession's oath of association before they are admitted. For the doctors the commitments are described in the Physician's (Hippocratic) Oath or in the Declaration of Geneva, as amended. Nurses have theirs in the Florence Nightingale Pledge while for pharmacists theirs is in the Pharmacist's Oath. A pledge or an oath which may not be legally binding is sure to be morally binding because it must bring all members to the same standard of professional behaviour and practice. In fact, it is because of the degree of value given to the oaths that scriptures warn against careless pledges (The Holy Bible KJV Numbers 30:2, Ecclesiastes 5:5). Therefore for standard and effective professional practice it is expected that pledges made must also be abided by. In abiding by the pledges the professional not only works for the employer but 
also represents the profession and the teachers as their ambassador in the place of employment.

When an inductee nurse signs to the Florence Nightingale Pledge to "pass my life in purity" purity in that pledge becomes an attitude of high ethical or moral value which the professional must ensure to uphold. In this case of purity the pledge indicates that the professional would endeavour not to be contaminated in the course of professional practice. And because one can only give what the individual has, the pure in conduct cannot make another impure since herself is not impure. Rather such an individual will contribute to the purity of the other. And knowing that impurity can also come by way of words, actions or thoughts the one will always refrain from such tendencies that lead to impurity in the virtues of the profession. Professionals who act this way show that they attach value to the pledge they make. It is also a demonstration of professionalism and it is shown in the affective domain of learning which is currently lacking among health workers when they go on strike.

\section{Delibrate actions versus intentions}

No individual has a right to be in the profession the individual practices. But the constitution of the Federal Republic of Nigeria provides for freedom of association. This therefore means that individuals have the freedom to be in the profession they have chosen to practice. But since the freedom to choose is a delibrate action, there is always an intention in the actions people take. Earlier it was held that one's intention also includes all consequences foreseen to be certain or probable. But in 1985 and 1986 in the cases involving $R . \quad v$ Moloney and $R . \quad v$ Hancock respectively, the matter is said to have been settled by the English law lords who held that it will be a fatal misdirection to continue in that old view (Finnis, 1991). Thus according to the law lord what one foresees to be probable or certain can no longer be held as one's intention. In other words, even if it is foreseable that strikes were to cause harm to patients, the harm done cannot be held as the intent in the strike. For in law and in carrying out an intention one does precisely what one intends or means to do, which in the case of strikes is cessation of work or reduction in the productivity of health personnel.

If the above explanation should be allowed to stand, one may ask, is a professional who embarks on strike which led to the death of a patient any less culpable than an influenza patient who goes to work thereby dropping those deadly viruses in the midst of his colleagues? This is because both acts of the sick going to work and the healthy going on strike were deliberate. Hence citing John Harris' Violence and Responsibility, Brazier and Harris (1996:179) are of the view that "we should take responsibility for the things we voluntarily bring about, not simply for what we intend, desire or wish to achieve". Surely the things we voluntarily bring about are deliberate.

\section{Public versus private interest}

With less than a fifty thousand doctors on the list of the MDCN to serve the projected one hundred and seventy million Nigerians, it can be against the public interest to embark on strike or even to take any appropriate legal action against health workers when they go on strike. An example was when the Federal Government in late 2014 terminated the appointment of striking resident doctors but later reversed the termination. Although a General Election was coming up in early 2015 any appropriate legal action against the doctors was bound to jeopardise the public interest. But it was not so for Israeli doctors who when they went on strike in 2011, although they got the demanded pay rise, they went back to work with a requirement to clock in and clock out of work (Steinberg, 2011). In this case both the public's interest and the private interest of the doctors were satisfied.

Furthermore, although it may not be easy to lay definite claim to the rightness or wrongness of an action because what is right to one may be wrong to another, yet any compliance or noncompliance to an oath or a pledge can easily be associated with rightness or wrongness of an action. In other words even deliberate actions that are self interest-centred (private interest) such as strikes with their intentions can only be tested by the workers' compliance or otherwise with professional oath or pledge. And compliance itself must be examined in the light of patient safety which has always been threatened in the Nigerian health system (McFubara, 2014a).

\section{Institutionalization of strikes}

When there is a strike in the health sector it is not just the personnel that are involved. It also affects all the components of the health system including 
the professional organizations and the health infrastructure. This makes strikes institutionalised. For the health system each of these component parts is essential but central among them is the health personnel. It is the health personnel who determines the status of the infrastructure as well as constitutes the membership of the professional organizations. And since these personnel come from different professions and represent different professional interests, there is always the demand from among themselves to protect their own interests rather than the public interest, through the decisions and actions they subscribe to. Thus when the personnel through their professional organizations withdraw their services the infrastructure in the system gets wasted due to ineffective use or non-utilization. Therefore in any justification of health sector strike what should be of concern is the compliance or non-compliance to the pledges made at induction by health personnel. Compliance or non-compliance which should be determined by the regulatory body is the only way to assure patient safety during strikes.

\section{CONCLUSION}

Health sector strike is neither supported by law, virtue ethics nor by the codes of professional practice. It is therefore unprofessional as it goes contrary to the pledges and oaths made at induction. Even so, despite the essential nature of health services, it seems that health sector strikes in Nigeria have become institutionalized. This is because health sector strikes affect every component of the health system. Although definite claim to the rightness or wrongness of the actions of health workers may be difficult, compliance or non-compliance to professional pledges can be identified with what is right or what is wrong. This is so because those to whom public health is entrusted have a duty and are under obligation to respect human dignity at all times. Moreover strikes in the health sector are not essentially because of dearth or decay of infrastructure and they are also not because of professional organizastions' intransigence. Rather they are the result of the loss of the value of professional ethics. That value which is the essence of health workers' calling is to save lives. To remedy this loss and curtail the spate of strikes in the health sector deliberate instructions in bioethics including clear elucidation of the pledges health workers make at induction should be given before they make the pledges. This should target the affective domain of their learning during training.

\section{REFERENCES}

Agboke, M., 2014. Industrial Relations and Conflict Resolution in the Health Sector. Journal of the Institute of Health Service Administrators of Nigeria, 18, (1): 48-54.

Alubo, S. O., 1986. The Political Economy of Doctors' Strikes in Nigeria: A Marxist's interpretation. Soc Sci Med 22, (4): 467477.

Amadi, O. S., 1996. A legal guide to trade unions. Afro Orbis publications.

BMA, 2015. (http://bma.org.uk/working-forchange/policy-and-lobbying/paynegotiations/nhs)

Brazier, M and Harris, J., 1996. Public Health and Private Lives. Medical Law Review, 4, Summer. 171-192.

Ezeani, C. O., 2000. Preface. In: Wakwe V.C., and Uche, E. E. O., (eds.). Fundamentals of bioethics in medical practice. Port Harcourt: University of Port Harcourt Press Ltd.

Federal Republic of Nigeria, 2014. National Health Act 2014.

Federal Republic of Nigeria, 2005. Trade Union (ammendment) Act, 2005.

Federal Republic of Nigeria, 2004. Trade Dispute (essential services) Act,

Finnis, J., 1991. Intention and side-effects. in Frey R.G and Morris C. (eds). Liability and responsibility. Cambridge: Cambridge University Press, 32, 33-35, 45-46.

Hamed, A., 2013. Islamic principles of Medical Ethics. A talk presented at the $\mathrm{KCL}$ National Conference for Islam and Medicine. 
(http://m.youtube.com/watch?v=cdpbGk8MsaM\&i tct)

Ihekweazu, C., 2010. The Minister of health, Resident doctors and Strikes. Nigrian Health Watch 18/08/2010. (www.nigeriahealthwatch.com/theminister-of-health- accessed 20/04/15).

Ikuomola, V., 2015. MDCAN faults resident doctors' strike. The Nation, June 30, 77.

Kemp, D. S., 2013. Can health care providers ethically go on strikes? (http://verdictjustia.com/2013/01/14/canhealth-care-providers-ethically-go-onstrike)

McFubara, K. G., 2014a. Professional rivalry and patient safety in Nigeria. Journal of the Institute of Health Service Administrators of Nigeria, 18, (1): 35-40.

McFubara, K. G., 2014b. The right to health and patient protection in Nigeria. Journal of the Institute of Health Service Administrators of Nigeria, 18, (1): 55-62.

McFubara, K. G., 1998. Health Policy in Nigeria: A case of the Flying Doctor Service in Rivers State. A PhD thesis submitted to the University of Manchester, UK.

nigeriahealthwatch.com/how-strikes-are-killingthe-public-healthcare-sector-and-why-itmay-be-difficult-to-reclaim/... (accessed 17/04/15,

Obebe, $\mathrm{K}$ and Adu, D., 2011. A practical cross boarder insight into employment and labour law. In The International Comparative Legal Guide to: Employment and Labour Law 2011. Global Legal Group.

Obembe, K., 2014. NMA warns JOHESU over planned strike (www.healthnewsng.com/2014/05/nmawarns-johesu-over-planned-strike)

http://nationalmirrowonline.net/news/nigeriashealth. (accessed 3/6/14, 11:56pm).
Ogundiran, T. O and Adebamowo, C. A., 2012. Medical ethics education: A survey of opinion of medical students in a Nigerian university. Journal of academic ethics 2012, 8, (2): 85-93.

Okeke, V., 2014. Time to halt incessant strikes in the health sector. (http://leadership.ng/news/386192/timeto-halt-incessant-strikes-health-sector) (accessed 17/04/15, published 06/10/2014).

Olalekan, A. W., Adeniran, O. O and Adebukola, A. M., 2010. Health workers perception of the use of strike as a tool for dispute resolution in Lagos State, Nigeria. Journal of Social Sciences and Public Policy. 2: 19-23.

Steinberg, J., 2011. After doctors' strike Israelis take stock of health care system woes. (www.jta.org/201109/18/news-opinion)

Stone, J. ed. 1995.. Medical Law Monitor. 